\title{
Застосування дифузійно-зважених зображень магнітно-резонансної томографіі для прогнозування перебігу хронічної хвороби нирок у хворих з нирково-клітинним раком після резекціі нирки
}

\author{
С. М. Пасічник ${ }^{1}$, Е. О. Стаховський ${ }^{2}$ Ю. Б. Борис ${ }^{1}$, Ю. О. Мицик ${ }^{1}$, Ю. Ю. Дутка ${ }^{3}$, \\ I. М. Комнацька ${ }^{3}$ \\ ${ }^{1}$ Львівський національний медичний університет імені Данила Галицького, \\ ${ }^{2}$ Національний інститут раку, м. Київ, \\ ${ }^{3}$ Медичний центр «Евроклінік», м. Львів

\section{Application of the diffusion-weighted images of the magnet-resonance tomography for prognostication of course of chronic renal disease in patients, suffering reno-cellular cancer after renal resection}

S. M. Pasichnyk ${ }^{1}$, E. O. Stakhovsky ${ }^{2}$, Yu. B. Borys ${ }^{1}$, Yu. O. Mytsyk ${ }^{1}$, I. Yu. Dutka ${ }^{3}$, I. M. Komnatska ${ }^{3}$

${ }^{1}$ Danylo Galytskyi Lviv National Medical University,

${ }^{2}$ National Cancer Institute, Kyiv,

${ }^{3}$ Medical Centre «Euroclinic», Lviv

\section{Реферат}

Мета. Вивчити можливість застосування дифузійно-зважених зображень магнітно-резонансної томографії (МРТ) для прогнозування розвитку хронічної хвороби нирок (XXH) у хворих із нирково-клітинним раком (НКР) після резекції нирки

Матеріали і методи. У дослідженні взяли участь 44 пацієнти, яких розподілили на дві групи: 1-шу (основну) склали 24 хворих, у яких вперше діагностували HКР стадій T1 aNOMOG1-G3, та 2-гу (контрольну) - 20 паціентів без ознак НКР та порушення анатомо-функціонального стану нирок.

Результати. Зниження вимірюваного коефіцієнта дифузії (ВКД) інтактної ділянки кори ураженої пухлиною нирки на дифузійно-зважених зображеннях МРТ у порівнянні із значеннями ВКД нормальної ниркової кори слугувало прогностичним маркером зниження швидкості клубочкової фільтрації на іпсилатеральній стороні, що можна розглядати як передумову розвитку XXН.

Висновки. Обчислення ВКД на дифузійно-зважених зображеннях МРТ дає можливість прогнозувати зниження функціональної здатності ураженої пухлиною нирки у хворих з НКР стадії Т1 а після іiі резекції, що є важливим для метафілактики розвитку ХХН у даної категорії хворих.

Ключові слова: нирково-клітинний рак; хронічна хвороба нирок; МРТ; дифузійно-зважені зображення; вимірюваний коефіцієнт дифузії; динамічна реносцинтиграфія

Abstract

Objective. To study the possibility of application of the diffusion-weighted images of the magnet resonance tomography (MRT) for prognostication of the chronic renal disease (CHRD) development in the patients, suffering renal-cellular cancer (RCC) after renal resection.

Materials and methods. In the investigation 44 patients, distributed into two groups, took part: in Group I (main) 24 patients were included, in whom for the first time a RCC was diagnosed in stages T1aNOM0G1-G3, and Group II (control) - 20 patients without signs of RCC and disorders of anatomic-functional state of the kidneys.

Results. Lowering of a measurable diffusion coefficient (MDC) in intact part of cortex in the oncologically affected kidney on the diffusion-weighted images of MRT in comparison with the MDC values of a normal renal cortex have served as a prognostic marker of lowering of velocity in glomerular filtration on ipsilateral side, what may be regarded as a condition for the CHRD development.

Conclusion. Calculation of MDC on the diffusion-weighted images of MRT makes possible to prognosticate the lowering of the functional capacity of kidney, effected by the tumor, in the patients, suffering RCC stage T1a after its resection, what is significant for metaprophylaxis of the CHRD development in this patients.

Keywords: reno-cellular cancer; chronic renal disease; MRT; diffusion-weighted images; measured coefficient of diffusion; dynamical renoscintigraphy.

В останні роки магнітно-резонансна томографія (МРТ) дедалі частіше привертає увагу клініцистів як метод вибору для діагностики та стадіювання нирково-клітинного раку (НКР), оскільки має низку переваг над комп'ютерною томографією: відмінна якість зображення, висока інформативність, пацієнт та персонал не зазнають будь- 
якого променевого навантаження, можливість отримання трьохвимірного зображення, оцінка функції нирок за допомогою контрастування тощо. За даними літератури, впровадження в медичну практику однієї з функціональних методик МРТ візуалізації - дифузійно-зважених зображень (Д33) - дає змогу досить ефективно застосувати контрастне зображення шляхом кількісного вимірювання теплового руху молекул води в тканинах організму [1]. Вимірюваний коефіцієнт дифузії (ВКД) - це кількісний показник, який розраховують на основі Д3З з метою подальшого використання оцінки ступеня дифузії в тканинах організму. Більшість клінічних систем МРТ (1,5T і 3Т) за наявності відповідного програмного забезпечення спроможні до модальності Д33 на доповнення до морфологічної та анатомічної візуалізації об'єкта [2, 3].

Беручи до уваги сказане, можна припустити, що МРТ 3 модальністю Дз3 може бути використано для ранньої діагностики та прогнозування розвитку ХХН у хворих 3 НКР стадії Т1а після виконання органозберігаючого хірургічного втручання без променевого навантаження на пацієнта.

Раніше ми повідомили про існування патоморфологічних змін інтактної паренхіми нирки, ураженої пухлиною, у хворих з НКР, які є прекурсорами розвитку ХХН, за відсутності змін біохімічних показників функції нирок (концентрації креатиніну, сечовини), тобто на доклінічному етапі [4].

Мета дослідження: вивчити можливість застосування Дз3 МРТ для прогнозування розвитку ХХН у хворих з НКР після резекції нирки.

\section{Матеріали і методи дослідження}

У дослідженні, проведеному з дозволу етичної комісії Львівського національного медичного університету імені Данила Галицького, взяли участь 37 хворих, які перебували на стаціонарному лікуванні в урологічному відділенні Львівської обласної клінічної лікарні. Усіх пацієнтів розподілили на дві групи: 1-шу (основну) - 17 пацієнтів, у яких вперше діагностували НКР на стадіях T1aNOMOG1G3, швидкість клубочкової фільтрації (ШКФ) становила 90 мл/хв/1,73 м² і більше та були ознаки сечового синдрому, та 2-гу (контрольну) - 20 пацієнтів без ознак НКР та порушення анатомо-функціонального стану нирок. У всіх пацієнтів не спостерігали жодних додаткових факторів ризику, які могли б впливати на анатомо-функціональний стан нирок. Вік хворих коливався від 45 до 69 років, у середньому становив $(57 \pm 2,1)$ року.

МРТ черевної порожнини проводили, використовуючи апарат Signa DFxt 1,5T (General Electric ${ }^{\circledR}$, США) та вось- миканальну котушку, за стандартним протоколом сканування, який, крім стандартних Т1 - та Т2- зважених зображень, передбачав отримання аксіальних Д3З з такими параметрами: час повтору $=11000$ мс, час ехо $=80$ мс, поле $3 о р у=40 \times 40$ см; матриця $=200 \times 192 ;$ пропускна здатність $=250$ кГц, напрям дифузіі = зріз, товщина зрізу = 6,0 мм, міжсканувальний розрив $=1,0$ мм з $\mathrm{b}-3$ наченнями 0 та 800 мм²/с. Д3З отримували до введення контрастної речовини за допомогою одномоментної ехо-планарної послідовності зображень з технікою паралельної візуалізації та насичення жиру протягом однієї затримки дихання. Додатковий час дослідження становив 18 с, середня тривалість обстеження - 34 хв.

Після проведення МРТ з кольорових карт, які автоматично генерувались на робочій станції на основі Д33, обчислювали ВКД, для чого встановлювали область зацікавлення (О3) на ВКД-карті над ділянкою кори нирки, ураженої пухлиною, максимально віддаленою від пухлини (інтактної паренхіми та кори нирки). Додатково обчислювали ВКД нормальної ниркової кори у здорових волонтерів, розміщуючи на МРТ-зображеннях О3 над відповідною ділянкою. У такий спосіб здійснювали вимірювання тричі, після чого вираховували середнє арифметичне отриманих даних. Для роботи із ВКД-зображеннями використовували програмний пакет робочої станціï Functool 4,5, MPT-зображеннями - програмний пакет RadiAnt DICOM Viewer 4.2.

Усім хворим з НКР безпосередньо до оперативного втручання та в середньому через 12 міс після нього виконували динамічну реносцинтиграфію із застосуванням гама-камери Infinia Hawkeye (General Electric ${ }^{\circledR}$, США) та 99mТс-ДТПА з активністю 200 МБк (ефективна доза - 1,3 м3в) у положенні лежачи. На основі отриманих даних визначали ШКФ для правої та лівої нирки окремо. Для опрацювання сцинтиграфічних даних застосовували програмний пакет Xeleris.

Результати оцінювали через 12 міс від початку проведення лікувально-діагностичних заходів. Статистичні дані опрацьовували з використанням прикладних статистичних методів за допомогою програмного пакета Microsoft Excel 2016.

\section{Результати}

У всіх хворих з НКР до резекції нирки за даними сцинтиграфії ШКФ перебувала в межах 90 - 95 мл/хв/1,73 м² та становила в середньому 92 мл/хв/1,73 м². Через 12 міс після проведеного лікування у 8 (47,1\%) хворих основної групи спостерігали достовірне зниження середнього значення ШКФ до $(82 \pm 0,23)$ мл/хв $/ 1,73$ м² $^{2}(\mathrm{p}<0,05)$. У решти

\begin{tabular}{|c|c|c|c|c|c|}
\hline \multicolumn{6}{|c|}{ ВКД ниркової кори у хворих під час первинного огляду, ( $\bar{x} \pm \sigma)$} \\
\hline \multirow{3}{*}{ Показник ШКФ } & \multirow{2}{*}{\multicolumn{2}{|c|}{ Число хворих }} & \multicolumn{2}{|c|}{ ВКД, $\times 10^{-3} \mathrm{Mm}^{2} / \mathrm{c}$} & \multirow{3}{*}{$\mathrm{p}$} \\
\hline & & & \multirow{2}{*}{ до резекції нирки } & \multirow{2}{*}{$\begin{array}{c}\text { нормальної ниркової } \\
\text { кори (контрольна група) }\end{array}$} & \\
\hline & абс. & $\%$ & & & \\
\hline Знижений & 8 & 33,3 & $1,7 \pm 0,3$ & $2,3 \pm 0,3$ & $<0,05$ \\
\hline Без змін & 16 & 66,7 & $2,2 \pm 0,4$ & $2,3 \pm 0,3$ & $>0,05$ \\
\hline
\end{tabular}


9 (52,9\%) хворих ціеї групи та у хворих контрольної групи середнє значення ШКФ достовірно не відрізнялось у порівнянні з вихідним показником - відповідно $(95 \pm 1,24)$ та $(97 \pm 0,31)$ мл/хв/1,73 м² і $(114 \pm 0,25)$ та $(117 \pm 0,23)$ мл/ $\mathrm{xв} / 1,73 \mathrm{M}^{2}$ ( $\left.\mathrm{p}>0,05\right) .3$ урахуванням того, що після резекції нирки у хворих отримані показники ШКФ, які різнилися між собою, було проведено ретроспективний аналіз значень ВКД ДЗЗ у цих хворих (див. таблицю), яким виявлено наявність прямого зв'язку між показниками ШКФ у хворих з НКР через 12 міс після операції та доопераційними показниками ВКд ДЗ3 МРТ: коефіцієнт кореляції Пірсона r=750 (p <0,05).

\section{Обговорення}

У хворих із зниженою ШКФ в ураженій пухлиною нирці через 12 міс після ії резекції передопераційне значення ВКД ДзЗ МРТ достовірно відрізнялось від значення даного показника у хворих контрольної групи в середньому на $35,3 \%$ ( $<<0,05)$. Водночас у хворих із незміненою ШКФ такої різниці не спостерігали (р>0,05). Таким чином, зниження ВКД інтактної ділянки кори нирки, ураженої пухлиною, на ДЗ3 МРТ у порівнянні із значеннями ВКД нормальної ниркової кори слугувало прогностичним маркером зниження ШКФ на іпсилатеральній стороні, що можна розглядати як передумову розвитку ХХН. Необхідні подальші дослідження для вивчення корелятивних зв'язків між ВКД та ШКФ у хворих з НКР.

\section{Висновки}

Обчислення ВКД на ДЗ3 МРТ дає змогу прогнозувати зниження функціональної здатності ураженої пухлиною нирки у хворих з НКР стадії Т1а після іiі резекції, що $€$ важливим для метафілактики розвитку ХХН у даної категорії хворих.

\section{Підтвердження}

Фінансування. За власні кошти дослідників.

Конфлікт інтересів. Автори заявляють, що вони не мають конфлікту інтересів.

Участь кожного автора. С. М. Пасічник - концепція і дизайн дослідження, написання тексту; Е. О. Стаховський - збір та опрацювання матеріалів; Ю. Б. Борис - збір та опрацювання матеріалів; Ю. О. Мицик - аналіз отриманих даних, написання тексту, I. Ю. Дутка - збір матеріалів, I. М. Комнацька - опрацювання матеріалів.

Всі автори прочитали і схвалили остаточний варіант рукопису.

Конфлікт інтересів. Автори декларують відсутністьконфлікту інтересів.

Згода на публікацію. Всі автори дали згоду на публікацію цього рукопису.

\section{References}

1. Dzygar OV, Babkina TM. The role of diffuse-weighted images of magnetic resonance imaging when controlling the quality of radiosurgical treatment of secondary tumor lesion of the liver. Clinical oncology. 2017;(4):77.[In Ukrainian].

2. Gill IS, Kavoussi LR, Lane BR, Blute ML, Babineau D, Coiombo JR $\mathrm{Jr}$, et al. Comparison of 1,800 laparoscopic and open partial nephrectomies for single renal tumors. J Urol. 2007;178(1):41-6. doi: 10.1016/j. juro.2007.03.038.

3. Mytsyk Y, Dutka I, Borys Y, Komnatska I, Shatynska-Mytsyk I, Farooqi AA, et al. Renal cell carcinoma: applicability of the apparent coefficient of the diffusion-weighted estimated by MRI for improving their differential diagnosis, histologic subtyping, and differentiation grade. Int Urol Nephrol. 2017;49(2):215-24. doi: 10.1007/s11255-016-1460-3.

4. Pasichnyk S, Stakhovsky O, Gozhenko A, Pasichnyk M, Voronina E. Ultrastructural changes in renal parenchyma with renal cell carcinoma. Journal of Education, Health and Sport. 2018;8(6):446-51. doi 10.5281/ zenodo.1495561.

Надійшла 14.01.19 